results, has followed operations performed upon those who had abstained from food for several hours. Possibly the surgical shock incidental to operations upon children bas not been so present in the mind of the author as have the requirements of the anæsthetist. The chapters which deal with the administration of the selected anæsthetic describe in some detail the method of giving nitrous oxide gas and that anæsthetic combined with oxygen or air, and gives a lengthy account of the apparatus which Dr. Hewitt finds most useful in each form of anæsthesia. For nitrous oxide anæsthesia, while admitting that there are hygienic objections to the practice, he favours the plan of permitting re-breathing of the gas towards the end of the inhalation. This plan, how ever, he says, leads to a less rapid recovery from the gas; nor, would it seem, has he observed the tendency to headache and sickness which some persons state follows this practice. The great freedom from all risk attendant upon the use of nitrous oxide is insisted upon, and the cautions given should be enough to ensure the proper administration of this valuable agent. The method of giving nitrous oxide mixed in some proportion with oxygen under the ordinary atmospheric pressure, popularised by Dr. Hillischer's well-known brochure, has been carefully studied, and the apparatus necessary simplified by Dr. Hewitt. His opinion of the mixture as he administers it is altogether favourable, except that he thinks that "after-effects" are a little more prone to follow its employment than when nitrous oxide is given unmixed. Even with Dr. Hewitt's admirable apparatus the method seems less simple than that requisite for unmixed gases-an objection, however, which is not likely to have weight if the results obtained are so undeniable as would appear. The descriptions in this book of the methods of giving ether are not so accurate, and in some cases, unless the apparatus referred to is familiar to the reader, it is probable that he will go astray and fail to achieve the best results obtainable if he follows the directions as expressed. The management and treatment of the difficulties and dangers of general anæsthesia are treated of in the third part of the volume. The preliminary note of apology for the length of this section seems hardly necessary in view of the great importance of the matters therein handled. This portion of Dr. Hewitt's volume is certainly one of its most useful features. It is clear and is rendered more forcible by a free introduction of illustrative cases.

Dr. Hewitt's book is a valuable one. It is well printed and illustrated, and the personality and experience of the author pervade every page, though due prominence is usually given and due respect paid to previous writers on the subject. Some may differ in opinion from, or demur to, the conclasions at which Dr. Hewitt has arrived, but no one can fail to recognise the honesty of purpose and the labour which have been brought to bear upon his task.

The London Lock Hospital.-On Saturday, April 21st, a well-attended dinner in aid of the London Lock Hospital and Rescue Home, Harrow-road, was held at the Whitehall Rooms of the Hotel Métropole. Lord Randolph Churchill, M.P., as chairman, proposed the toast of the evening. He called attention to the position which the institution oocupied in the metropolis. It was the only one of the kind in London, and the number of applicants for the benefits it conferred could hardly be small. The support was not so great as a hospital of this kind deserved, and a large debt had been incurred. On account of the diminution of the funds some of the wards had been closed, and he hoped that all well-thinking men would come to its rescue. Lord Kinnaird, in replying for the hospital, said the sum of $£ 5000$ was urgently needed, of which $£ 2000$ had already been promised. During the course of the evening donations to the amount of nearly $£ 3000$ were announced, including $£ 500$ from Baron Hirsch.

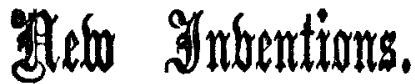

\section{A NEW FORM OF NEEDLT FOR LIGATURING THE BROAD LIGAMENTS IN CASES OF VAGINAL} HYSTERECTOMY.

HAVING read Mr. Braithwaite's article on clamping the broad ligaments in cases of vaginal hysterectomy for cancer, I beg to draw attention to a new form of needle that has been made for me by Messrs. Weiss and Son for the purpose of ligaturing the broad ligaments. Every surgeon who has had any experience in the operation has recognised the diff. culty that exists in ligaturing the broad ligaments by means of the ordinary needles. The needles, as suggested by me, will be seen by the figure to be furnished with a long arm with a large eye; this arm runs pretty nearly parallel with the main staff. The method of applying the needle is thus. The os and cervix uteri being thoroughly freed and the peritoneum opened up before and behind, the needle is passed over the uterus on the flat until the point is felt by the index-finger to be well above the uterine artery; then, by
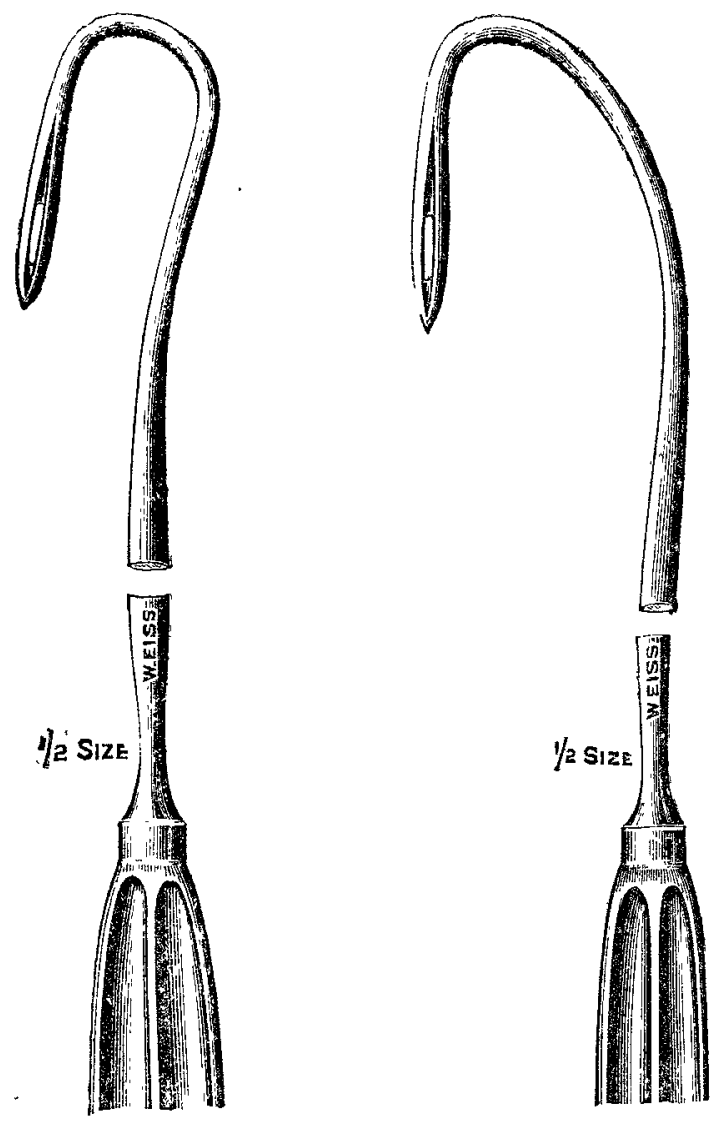

raising the handle and slightly twisting the needle, the point, being guided by the finger to the spot it is required to pierce, is forced completely through the broad ligament as close to the uterus as necessary; the point is then carried down the opposite side of the ligament and brought out through the vagina; a ligature is now passed through the eye, and the needle is withdrawn. This manceurre is repeated on the opposite side, and the uterine arteries are secured, the uterus being further freed by dividing the tissues between it and the ligature. The broad ligament can thus be tied in segments until the uterus is completely freed. I am convinced that surgeons who, like myself, prefer ligaturing to clamping the broad ligament in this operation will readily recognise the advantage of adopting these needles. I have now used them in some thirty cases during the last eighteen months and can safely say that in some cases in which it was impossible to draw the cervix down through the valva I should have had the greatest difficulty in ligaturing the uterine arteries without the aid of these needles.

F. Bowneman Jessmit, F.R.C.S. Buckingham Palace Mansions, S. W. 